Огляди літератури, оригінальні дослідження, погляд на проблему, випадок з практики, короткі повідомлення УДК 616-002.5-06:616.98: 089

DOI 10.11603/1811-2471.2020.v.i2.11325

\title{
ЕФЕКТИВНІСТЬ УЛЬТРАЗВУКОВОї ДІАГНОСТИКИ ТУБЕРКУЛЬОЗНОї ЕМПІєМИ ПЛЕВРИ
}

๑ю. Ф. Кошак

\section{Тернопільський національний медичний університет імені І. Я. Горбачевського МОЗ України}

РЕзЮМЕ. Представлено перший ефективний аналіз ранньої діагностики хворих на туберкульозну емпієму плеври за допомогою ультразвукового дослідження органів грудної клітки. Проаналізовано ультразвукові особливості стадійності, локалізації в діагностиці туберкульозної емпієми плеври в залежності від статі, віку, початку, перебігу та поширеності нагноєння.

Мета - покращити результати ультразвукової діагностики хворих із туберкульозною емпіємою плеври шляхом проведення аналізу цінності стандартних методів діагностики.

Матеріал і методи. Проведений ретроспективний аналіз 685 випадків туберкульозної емпієми плеври у пацієнтів, які за останні 10 років отримали стаціонарне лікування у фтизіохірургічному відділенні «ТОПД». Усім хворим були проведені необхідні клінічні, лабораторні та інструментальні, включаючи ультразвукові, рентгенологічні та імунологічні методи обстеження.

Результати. Встановлено, що ультразвукове дослідження має цілий ряд переваг і $є$ високоінформативним методом діагностики плеврального нагноєння. За даними ехосканувального дослідження можна спрогнозувати характер плеврального випоту.

Висновки. Лише у 51,2 \% хворих на туберкульозну емпієму плеври захворювання було діагностовано своєчасно, тобто на стадії можливого малоінвазивного хірургічного лікування. Найбільші діагностичні труднощі трапляються у пацієнтів з локалізацією емпієми плеври у зоні активних туберкульозних або метатуберкульозних змін. У 48,7 \% хворих туберкульозна емпієма була діагностована на пізній стадії гнійного процесу, що підтверджує нео6хідність широкого застосування в діагностиці ультразвукового дослідження.

КлючОВІ СлОВА: туберкульоз; ультразвукове дослідження; туберкульозна емпієма плеври; відеоторакоскопія; відеоасистована хірургічна резекція; відкрита плевректомія з декортикацією легені.

Вступ. Емпієми плеври пов'язані перш за все із невстановленою причиною різноманітних за етіопатогенезом захворювань: 1) специфічні (туберкульоз, актиномікоз, нагноєні плеврити, набутий імунодефіцит, ВІЛ-інфекція), 2) неспецифічні (парапневмонічні, параканкрозні, септичні), 3) посттравматичні (згорнуті гемоторакси, пневмоторакси), 4) застійні (серцеві, післяопераційні) тощо. Низький рівень сучасної діагностики туберкульозної емпієми плеври за наведеними вище категоріями призводить до зростання захворюваності на туберкульоз. Раціональний вибір сучасної діагностики та бактеріологічні дослідження на змішану флору значно зменшують формування резистентності нагноєння при туберкульозній емпіємі плеври. Проаналізовано ультразвукові особливості туберкульозної емпієми плеври та результати мінімально інвазивного лікування. При вивченні етіології туберкульозного нагноєння у хворих встановлено, що облітерація плевральної порожнини, фіброзно-склеротична деформація легеневої паренхіми та нагноєння залишкової плевральної порожнини створюють технічні труднощі у встановленні етіологічної причини туберкульозного ураження плеври. Все це викликає латентний перебіг нагноєння плеври, хронізацію процесу та інвалідизацію хворого, що є актуальними в сучасній медицині.

Мета - покращити результати ультразвукової діагностики хворих із туберкульозною емпіємою плеври шляхом проведення аналізу цінності стандартних методів діагностики.

Матеріал і методи дослідження. Проведений ретроспективний аналіз 685 випадків туберкульозної емпієми плеври у пацієнтів, які за останні 10 років отримали стаціонарне лікування у фтизіохірургічному відділенні «ТОПД». Усім хворим були проведені необхідні клінічні, лабораторні та інструментальні, включаючи ультразвукові, рентгенологічні та імунологічні методи обстеження. При аналізі діагностичних алгоритмів нами були виділені їх основні групи, які дозволили провести діагностику появи туберкульозної емпієми плеври в залежності від початку, статі, віку, локалізації, стадії та поширеності гнійного процесу.

Результати й обговорення. Прооперованих хворих було поділено на дві групи: 351 (51,25 \%) пацієнт, прооперований із застосуванням малоінвазивних технологій (VTS, VATS), склав основну групу; 334 (48,75 \%) хворих, яких було прооперовано відкритою боковою торакотомією (ПЕ з ДЛ), склали групу порівняння. Із 351 пацієнта основної групи - у 301 відмічено гостру туберкульозну емпієму плеври, у 50 - хронічну. Серед пацієнтів групи порівняння гостра емпієма плеври встановлена у 284 хворих, а хронічна -у 50.

У результаті порівняння інструментальних методів діагностики УзД із результатами цифрової поліпозиційної флюорографії, рентгенографій та 
Огляди літератури, оригінальні дослідження, погляд на проблему, випадок з практики, короткі повідомлення КТ органів грудної клітки за появою емпієми плеври встановлено, що ультразвукове дослідження має цілий ряд переваг і є високоінформативним методом діагностики плеврального нагноєння. За даними ехосканувального дослідження можна спрогнозувати характер плеврального випоту: 1) вільний плевральний випіт формує ехогенну зону, яка на моніторі сканера відслідковується у вигляді анехогенних смуг різної величини і протяжності; 2) серозно-геморагічний випіт зазвичай має однорідну ехоструктуру; 3) геморагічний випіт теж має однорідну структуру, але дуже низьку ехогенність; 4) серозно-фібринозний випіт характеризується неоднорідністю, що часто спостерігається при туберкульозній емпіємі (I стадія емпієми); 5) серозно-гнійний випіт також характеризується неоднорідністю структури ексудату із появою ділянок, острівків гіперехогенного характеру (II стадія емпієми); 6) фіброзна організація випоту характеризується ділянками склерозу, грубого фіброзу, секвестрації гіперехогенного характеру, порушенням екскурсії легеневої тканини та діафрагми, звуженням міжреберних проміжків (III стадія емпієми плеври).

У 351 пацієнта основної групи було проведено діагностичну пункцію. В 301 хворого встановлено серозно-гнійний випіт (I-ІІ стадія емпієми), що збігалося з даними УЗД у 90,2 \% випадків. Фіброзногнийній випіт виявлено у 50 пацієнтів (III стадія емпієми), що збігалося за даними ультразвуку у 95,6 \% випадків. При серозно-геморагічному випоті збіг з даними УЗД склав 85,6 \% випадків.

Інформативність ультразвукового дослідження наведено на рисунку 1.

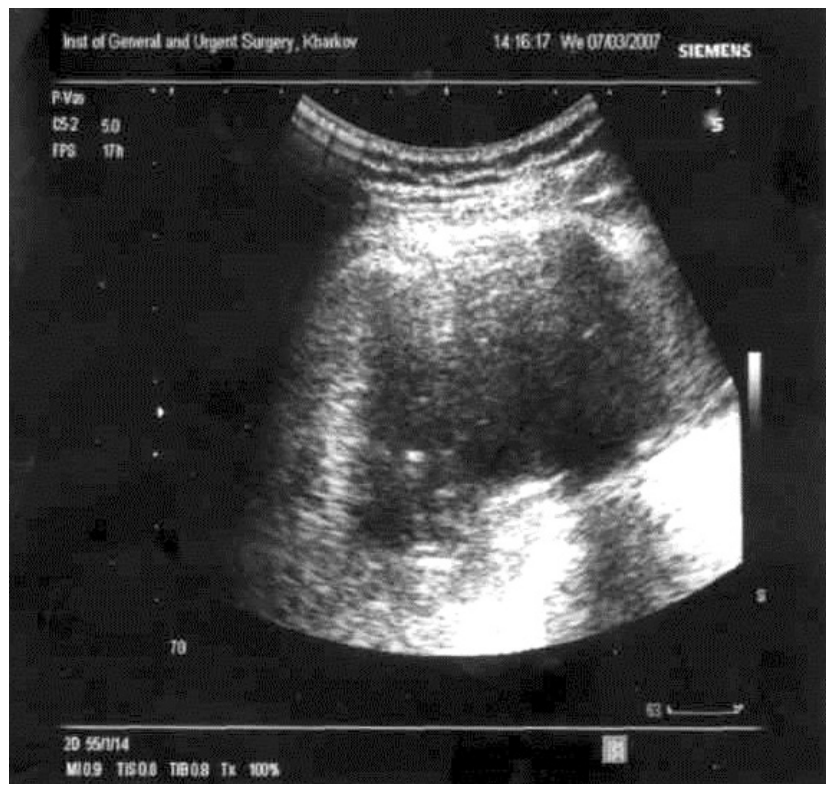

Рис. 1. Ультразвукове дослідження пацієнта М., 48 р., осумкований серозно-геморагічний випіт справа із нагноєнням.
УЗД плевральної порожнини ефективно виявило згорнутий гемоторакс, який було підтверджено плевральною пункцією та відеоторакоскопічною операцією. Дослідження ехосканування дає можливості діагностувати випоти як великого, так і малого об'єму. Мінімальний об'єм рідини в плевральній порожнині, який ми візуалізували на екрані, становив від 10-15 мл. При великих випотах, які перевищують 500 мл, дані стають видимі при рентгенологічному дослідженні. Саме висока інформативність УЗД відмічена при малих осумкованих, пристінкових та наддіафрагмальних емпіємах плеври. Для туберкульозної емпієми плеври характерна поява середніх випотів - 300-500 мл, які часто мали серозно-гнійний характер. У 65 пацієнтів, які увійшли в наше дослідження з приводу осумкованих емпієм, рентгенологічні дослідження вільної рідини не виявили. Натомість УЗД показало наявність вільної рідини до 100 мл, яка була видалена додатковими пункціями. При паракостальній локалізації осумкування рідина мала плащоподібну форму в 40 випадках, та лінзоподібну - в 25, що утруднювало їх діагностику на рентгенографії. Інформативність даного методу відображено на рисунку 2.

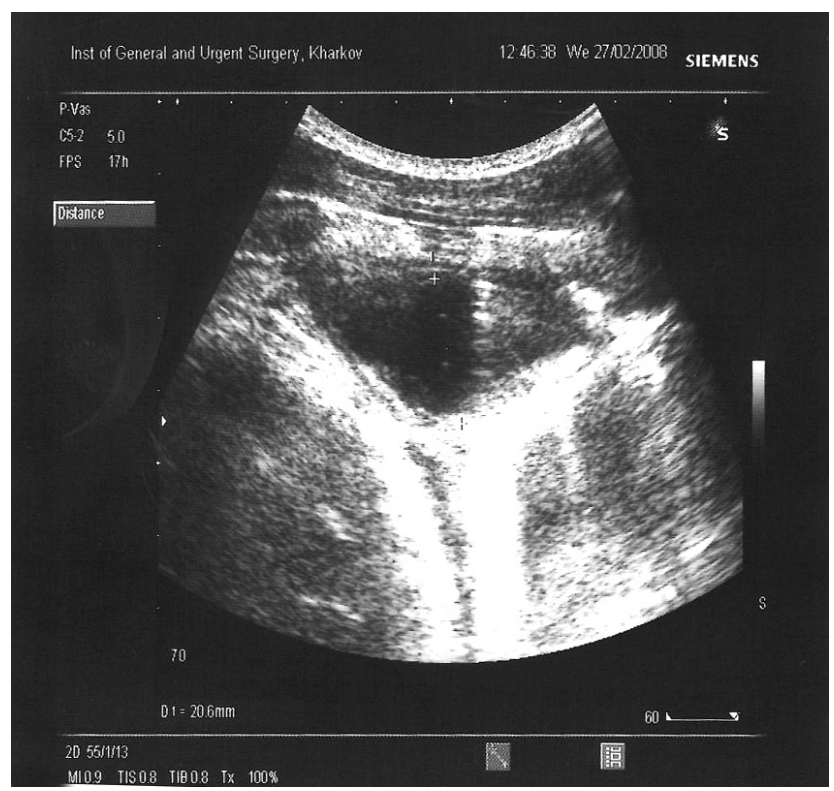

Рис. 2. Ультразвукове дослідження пацієнта Г., 54 р., осумкований серозно-гнійний випіт зліва об'ємом 30 мл.

Як видно з рисунка 2, в лівій плевральній порожнині виявлено осумкований випіт, а при плевральній пункції було видалено серозно-гнійну рідину в кількості 20 мл з наступним бактеріоскопічним та цитологічним дослідженнями. Діагноз туберкульозної емпієми було підтверджено цитологічним висновком: виявлено епітеліоїдні клітини та клітини Пирогова - Ланхганса. 
Огляди літератури, оригінальні дослідження, погляд на проблему, випадок з практики, короткі повідомлення

Позитивними сторонами ультразвукового дослідження $\epsilon$ ефективність диференційної діагностики між випотом та спайковим процесом у грудній клітці. При наявності зрощень у плевральній порожнині чітко візуалізуються лінійні ехоструктури високої ехогенності. На УЗД також можна виявити осумковану рідину серед зрощень. Встановлення спайкового процесу в плевральній порожнині в ряді випадків дозволяє уникати необґрунтованих пункцій та операцій. У наших дослідженнях саме УзД показало високу інформативність при діагностиці осумкованих емпієм, що відображено на рисунку 3.

При виявленні на УЗД осумкування вдалося чітко візуалізувати його межі. Неоднородність внут-

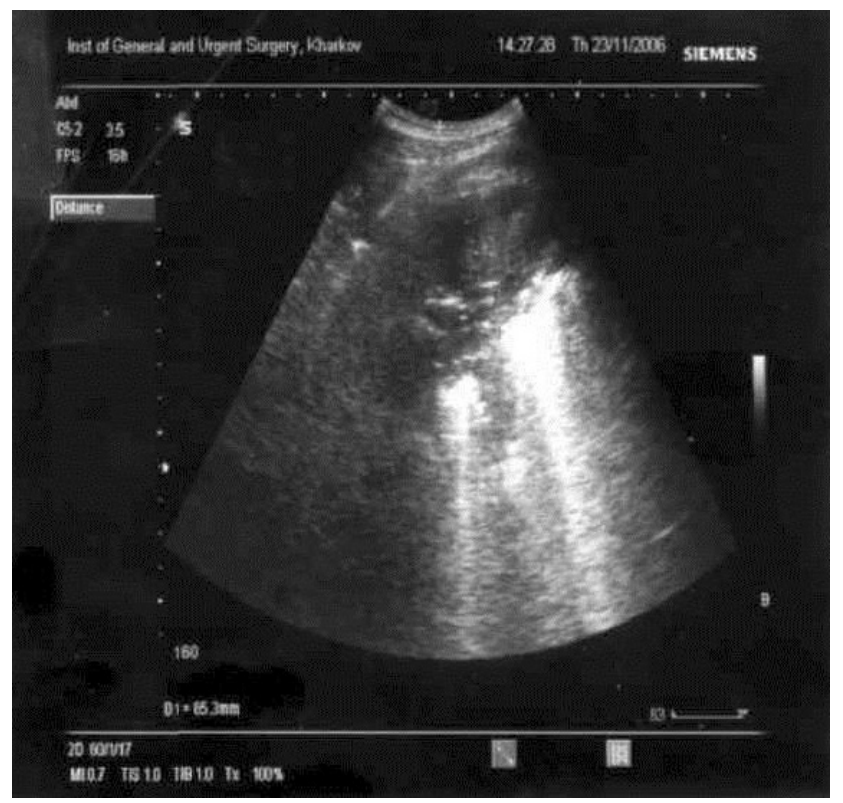

Рис. 3. Ультразвукове дослідження пацієнтки Л., 38 р., виражений спайковий процес у лівій плевральній порожнині.

При ультразвуковому дослідженні виявлено три відмежованих осумкування. При цьому в одному осумкуванні відмічені спайки, які зміщувались у такт дихання. Ця ультразвукова ознака вказує на те, що спайки не перекривають плевральну порожнину. Завдяки УЗД у всіх хворих із багатокамерною локалізацією емпієми плеври хірургічні методи лікування виявилися ефективними.

Ультразвукове дослідження плевральної порожнини виявилося високоінформативним діагностичним методом у комплексі діагностики гострої туберкульозної емпієми плеври. Його використання стало ефективним для встановлення меж, структури, локалізації осумкування та орієнтовної стадії нагноєння в грудній клітці. Дослідження завжди допомагало в проведенні диференційної діагностики між спайковим процесом та вільною ріди- рішньої ехоструктури була обумовлена гнійним вмістом, фібрином та детритом. Випіт при емпіємі дає внутрішні ехосигнали, які наче «плавають» у такт дихання та при зміні положення тіла пацієнта. На значній ділянці добре контуруються потовщення листків плеври. В окремих випадках спайки повністю не перекриваються і провисають у вигляді фібринових тяжів. Перераховані дані дослідження дуже важливі для встановлення мітки для проведення пункції чи торакоцентезу із дренуванням. До позитивних сторін ультразвукового дослідження належить можливість визначення самої нижньої точки емпіємної порожнини, в яку необхідно встановити санаційний дренаж. Характер багатокамерної емпієми плеври відображено на рисунку 4.

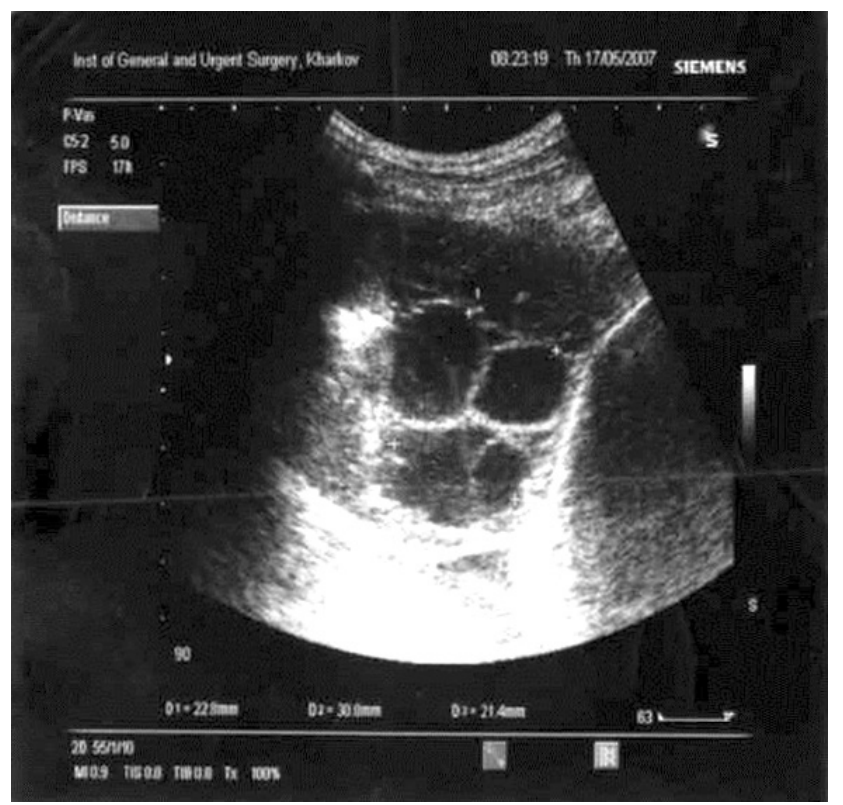

Рис. 4. Ультразвукове дослідження пацієнта Г., 52 р., наявна багатокамерна емпієма плеври.

ною. Встановлення залишкової порожнини давало можливості ставити мітку для проведення лікувального торакоцентезу в найнижчій точці нагноєння в грудній клітці. Поєднане використання рентгенологічного та ультразвукового досліджень плевральної порожнини підвищує ефективність діагностичних передопераційних досліджень, що дозволяє знизити променеве навантажнення на хворого.

«Специфічність» туберкульозної емпієми плеври $\epsilon$ достатньо умовним терміном, оскільки, за даними клінічного перебігу, в порожнині нагноєння завжди наявні змішана бактеріальна грампозитивна і грамнегативна мікрофлора, гриби та віруси. Схематично це відображено на рисунку 5.

Ультразвукове дослідження допомогло встановити туберкульозну емпієму плеври в 1-ій, 2-ій 
Огляди літератури, оригінальні дослідження, погляд на проблему, випадок з практики, короткі повідомлення

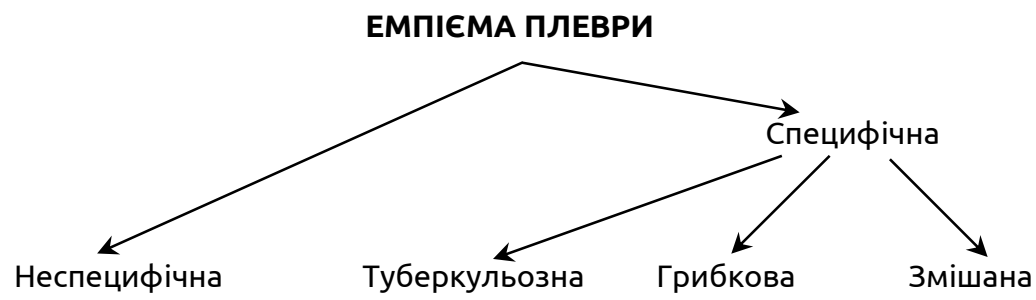

Рис. 5. Емпієми плеври залежно від специфічності процесу.

та 3-ій стадіях її розвитку, результати відображено в таблиці 1.

Наведені дані підтверджують, що у більшості пацієнтів туберкульозну емпієму плеври діагностують у I-ІІ стадіях захворювання. У результаті по- грішностей в консервативному лікуванні цей процес набуває періодично прогресуючого хронічного перебігу.

Розподіл пацієнтів обох груп дослідження за статевою ознакою відображено в таблиці 2.

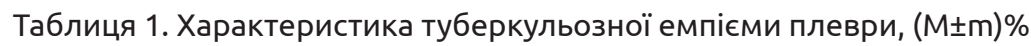

\begin{tabular}{|c|c|c|c|c|}
\hline \multirow{2}{*}{$\begin{array}{c}\text { Показник } \\
\text { туберкульозного процесу }\end{array}$} & \multicolumn{2}{|c|}{$\begin{array}{c}\text { Основна група, } \\
\text { n=351 }\end{array}$} & \multicolumn{2}{|c|}{$\begin{array}{c}\text { Група порівняння, } \\
\text { n=334 }\end{array}$} \\
\hline & a6c. & $(M \pm m) \%$ & a6c. & $(M \pm m) \%$ \\
\hline Гостра ТЕП & 301 & $85,7 \pm 1,3 *$ & 284 & $85,0 \pm 1,7 *$ \\
\hline Хронічна ТЕП & 50 & $14,2 \pm 0,3 *$ & 50 & $14,9 \pm 0,3 *$ \\
\hline$p$ & \multicolumn{4}{|c|}{$p<0,05$} \\
\hline
\end{tabular}

Примітка* - різниця між групами достовірна $(p<0,05)$.

Таблиця 2. Розподіл пацієнтів за статтю, $(\mathrm{M} \pm \mathrm{m}) \%$

\begin{tabular}{|c|c|c|c|c|}
\hline \multirow{2}{*}{ Стать } & \multicolumn{2}{|c|}{ Основна група } & \multicolumn{2}{|c|}{ Група порівняння } \\
\hline & a6c. & $(\mathrm{M} \pm \mathrm{m}) \%$ & a6c. & $(M \pm m) \%$ \\
\hline Чоловіки & 264 & $75,2 \pm 1,3 *$ & 254 & $76,1 \pm 1,7$ * \\
\hline Жінки & 87 & $24,7 \pm 0,3 *$ & 80 & $23,9 \pm 2,2 *$ \\
\hline Всього & 351 & $100 \% *$ & 334 & $100 \% *$ \\
\hline$p$ & & & & \\
\hline
\end{tabular}

Примітка * - різниця між групами достовірна $(p<0,05)$.

Більшість пацієнтів із туберкульозною емпіємою плеври становили чоловіки 75,2 - 76,1 \%, натомість жінки склали 23,9-24,7 \% випадків.

Аналіз вікових груп показав, що вік хворих коливався від 18 до 80 років. Частка пацієнтів працездатного віку, до 60 років, в основній групі становила 80,9 \%, в порівняльній - 81,8 \%. Максимальна кількість хворих обох груп припадала на вікову категорію 31 - 70 років. Тенденція до збільшення пацієнтів старшого віку потребує подальшого вивчення з урахуванням вікових особливостей та наявної супутньої патології.

В обох групах переважали хворі із емпіємою плеври при легеневому туберкульозі та фібринозному туберкульозному плевриті, який ускладнився нагноєнням плеври. В основній групі вони склали $79,48 \%$, а в порівняльній - 82,03 \% випадків. Наявність в обох групах пацієнтів із посттравматичною емпіємою, змішаними та післяопераційними нагноєннями вказує на неефективність консервативно- го лікування, проведеного на попередніх етапах. У більшості випадків туберкульозної емпієми плеври, в 57,8 \%, спостерігалася поява вторинної емпієми при легеневому туберкульозі, у 21,6 \% випадків емпієма розвинулася самостійно при туберкульозному плевриті. Бронхіальні фістули діагностували у 11,7 \% випадків туберкульозної емпієми плеври. У пацієнтів з гострою емпіємою плеври тривалість захворювання склала не більше 1-2 місяців.

Розподіл пацієнтів із туберкульозною емпіємою плеври за локалізацією процесу наведено в таблиці 3.

У наших дослідженнях в обох групах переважали хворі із правобічною локалізацією туберкульозної емпієми плеври. Характеристики груп хворих дозволили зробити висновки, що пацієнти основної та порівняльної груп достатньо близькі за наведеними параметрами. Це дозволило в подальшому об'єктивно порівнювати результати діагностики та лікування. 
Огляди літератури, оригінальні дослідження, погляд на проблему, випадок з практики, короткі повідомлення

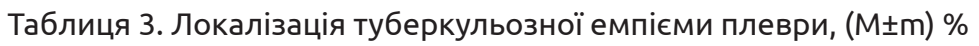

\begin{tabular}{|c|c|c|c|c|}
\hline \multirow{2}{*}{ Локалізація процесу } & \multicolumn{2}{|c|}{ Основна група } & \multicolumn{2}{|c|}{ Група порівняння } \\
\hline & a6c. & $(M \pm m) \%$ & a6c. & $(M \pm m) \%$ \\
\hline Правобічна & 230 & $65,5 \pm 2,3 *$ & 236 & $56,1 \pm 3,2^{*}$ \\
\hline Лівобічна & 92 & $26,2 \pm 1,6^{*}$ & 86 & $42,1 \pm 2,3^{*}$ \\
\hline Двобічна & 29 & $8,2 \pm 0,6^{*}$ & 12 & $1,8 \pm 0,3 *$ \\
\hline Всього & 351 & $100 \% *$ & 334 & $100 \% *$ \\
\hline$P$ & \multicolumn{4}{|c|}{$p<0,05$} \\
\hline
\end{tabular}

Примітка* - достовірна різниця між групами (p<0,05).

При проведенні спіральної комп'ютерної томографії без контрастного підсилення вдалося виявити характерні ознаки нагноєння лише у 492 $((71,8 \pm 1,9) \%)$ з цих пацієнтів $(p<0,05)$. При цьому візуалізація туберкульозу легень була можлива у $406((59,8 \pm 3,0) \%)$ хворих з туберкульозною емпіємою плеври, з вторинними ознаками піопневмотораксу - лише у $128((18,7 \pm 2,9) \%)(p<0,05)$. Характерна для туберкульозу неоднорідність потовщен-

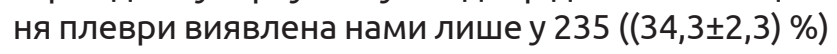
пацієнтів, а деструкція в легені ще рідше - у 86 $((12,5 \pm 3,1) \%)$. СКТ-ознаки вогнищевої інфільтрації легені були чітко визначені у $192((28,1 \pm 3,0) \%)$ пацієнтів, тоді як виявлення туберкульоми легень -

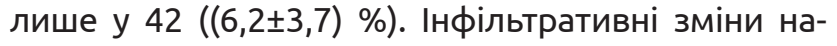
вкруги деструкції легень виявлялися на СКТ, при цьому їх було складно відрізнити від інфільтрації не туберкульозного походження $(p<0,05)$. Аналіз за результатами СКТ до операції порівнювали з результатами інтраопераційної ревізії з подальшою біопсією та патогістологічними дослідженнями.
Із 685 хворих на туберкульозну емпієму плеври лише у 351 (51,2 \%) вона була вірогідно діагностована своєчасно та цим пацієнтам проведено малоінвазивне хірургічне лікування, вони склали основну групу даного наукового дослідження. Решта 334 (48,7 \%) пацієнти були визнані хворими із занедбаною емпіємою плеври, їм було виконано відкриту операцію плевректомії з декортикацією легені.

В усіх хворих обох груп спостереження обов'язковим було проведення патогістологічного дослідження біопсійного матеріалу, резектатів легені та ураженої плеври. Ми провели поділ клінічних випадків на 4 категорії, що представлено в таблиці 4:

1. Емпієма плеври на фоні легеневих туберкульозних змін;

2. Туберкульозний плеврит, ускладнений емпіємою плеври;

3. Змішані емпієми плеври;

4. Післяопераційні емпієми плеври;

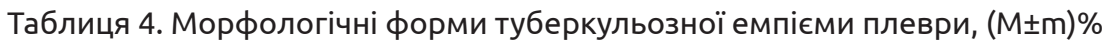

\begin{tabular}{|c|c|c|c|c|}
\hline \multirow{2}{*}{ Морфологічні форми } & \multicolumn{2}{|c|}{ Основна група $(n=351)$} & \multicolumn{2}{|c|}{ Група порівняння (n=334) } \\
\hline & a6c. & $(M \pm m) \%$ & a6c. & $(M \pm m) \%$ \\
\hline Емпієма при туберкульозі & 203 & $57,4 \pm 2,6^{*}$ & 200 & $59,6 \pm 1,8 *$ \\
\hline Потовщення плеври & 65 & $18,5 \pm 2,2^{*}$ & 26 & $7,7 \pm 2,7^{*}$ \\
\hline Лімфангіїт плеври & 36 & $10,2 \pm 0,1 *$ & 17 & $5,1 \pm 0,6^{*}$ \\
\hline Міліарні горбики & 40 & $11,3 \pm 1,0 *$ & 33 & $9,8 \pm 3,2^{*}$ \\
\hline Казеозні виразки, некрози & 28 & $7,9 \pm 3,6 *$ & 30 & $8,9 \pm 3,2 *$ \\
\hline Гіалінізація плеври, фіброз & 24 & $6,8 \pm 5,2^{*}$ & 47 & $14,1 \pm 2,4 *$ \\
\hline Бронхолегеневі фістули & 7 & $1,9 \pm 2,9 *$ & 43 & $12,8 \pm 3,9 *$ \\
\hline Плевроторакальні нориці & 3 & $0,8 \pm 1,3^{*}$ & 4 & $1,2 \pm 0,9 *$ \\
\hline $\begin{array}{l}\text { Туберкульозний плеврит, } \\
\text { ускладнений емпіємою }\end{array}$ & 76 & $21,6 \pm 2,1^{*}$ & 74 & $22,1 \pm 2,3^{*}$ \\
\hline Змішані емпієми плеври & 44 & $12,5 \pm 2,6 *$ & 40 & $11,9 \pm 1,8 *$ \\
\hline Післяопераційні емпієми & 28 & $7,9 \pm 3,2^{*}$ & 20 & $5,9 \pm 0,6^{*}$ \\
\hline $\mathbf{p}$ & & & & \\
\hline
\end{tabular}

Примітка: * - p- рівень значимості за критерієм $\chi^{2}$ Пірсона у основній групі та групі порівняння $(p<0,05)$.

Цитологічне дослідження. Альвеолоцити I типу та ендотеліоцити кровоносних капілярів плеври мали ознаки внутрішньоклітинного на- бряку. Цитоплазма їх вміщувала невелику кількість рибосом та полісом, мала зруйновані кристи. Зустрічалися мітохондрії зі зруйнованими зов- 
Огляди літератури, оригінальні дослідження, погляд на проблему, випадок з практики, короткі повідомлення нішніми мембранами. У відростках альвеолоцитів I типу та ендотеліоцитів кровоносних капілярів були практично відсутні мікропіноцитозні бульбашки. Мезотеліальні клітини мали деструктивні зміни. Але при високій вірулентності мікобактерій туберкульозу в рідині дуже швидко приєднувалася вірулентна грам (-) флора, і ексудат переходив із серозного в гнійний. Санація з активним пункційним очищенням емпіємної порожнини та санація з плевросорбцією істотно стимулювала репаративні процеси альвеолоцитів II типу. Підтвердженням цього є гіперплазія мембран гранулярної ендоплазматичної сітки. Знижується рівень вираження мітохондріальної дисфункції, з'являються поділені форми мітохондрій. Активуються репаративні внутрішньоклітинні процеси, що підтверджується гіперплазією мембран гранулярного ендоплазматичного ретикулума. Альвеолярні макрофаги перебувають у метаболічно активному стані. Мезотеліальні клітини мали ознаки відновлення їх субмікроскопічної організації (дуже рідко з'являлися осередки лізису каріолеми, збільшувалася кількість рибосом та полісом, зменшувався набряк мітохондрій, цитоплазма-

тична мембрана потовщувалась та розпушувалась). Морфологічні зміни при ТБЕ значно відрізнялися від туберкульозних плевритів потовщенням парієтальної плеври (до 3-5 см) за рахунок новоутворених колагенових волокон, гіалінізації фіброцитів та фібробластів. В ній виявляються епітеліоїдні горбики із гігантськими клітинами Пирогова-Ланхганса.

Висновки. Лише у 51,2\% хворих на туберкульозну емпієму плеври захворювання було діагностовано своєчасно, тобто на стадії можливого мінімально інвазивного хірургічного лікування. Аналіз діагностичної цінності стандартних методів діагностики туберкульозного нагноєння у хворих на туберкульоз показав, що своєчасне виявлення такого ускладнення становить значні труднощі. Найбільші діагностичні труднощі трапляються у пацієнтів з локалізацією емпієми плеври у зоні активних туберкульозних або метатуберкульозних змін. У 48,7 \% хворих туберкульозна емпієма була діагностована на пізній стадії гнійного процесу, що підтверджує необхідність широкого застосування в діагностиці ультразвукового дослідження.

\section{ЛІТЕРАТУРА}

1. Эмпиемы плевры. Оперативные методы лечения. Часть III [Текст] / Е. А. Цеймах [и др.] // Туберкулез и болезни легких. - 2010. - № 2. - С. 5-12.

2. Применение ранней видеоторакоскопической декортикации легкого в лечении острой эмпиемы плевры и нагноившегося свернувшегося гемоторакса [Текст] / П. П. Шипулин [и др.] // Клініч. хірургія. - 2010. № 10. - С. 29-31.

3. Можливості ультразвукового дослідження плевральних порожнин у діагностиці стадії емпієми плеври [Текст] / В. І. Перцов, Я. В. Тєлушко, С. І. Савченко // Запорож. мед. журн. - 2018. - Т. 20, № 4. - С. 487-490.

4. Опанасенко М. С. Ендоскопічні методи лікування підгострих і хронічних запальних захворювань плеври [Текст ] / М. С. Опанасенко, С. М. Шалагай, Е. В. Климець// Клініч. хірургія. - 2017. - № 1. - С. 39-42.

5. Дужий І. Д. Питання епідеміології емпієми плеври [Текст] / І. Д. Дужий, І. Я. Гресько, Ю. О. Міщенко // Укр. Пульмон. Журнал. - 2016. - № 3. - С. 60-63.

6. Баландина И. А. Дренирование плевральной полости при острой эмпиеме / И. А. Баландина, Д. Г. Амарантов // Хирургия. Журнал имени Н. И. Пирогова. 2011. - № 2. - С. 33-36.

7. Опанасенко М. С. Обгрунтування ефективності використання відеоасистованого доступу в хірургії запальних процесів плеври / М. С. Опанасенко С. М. Шалагай, Е. В. Климець // Клініч. хірургія. - 2017. - № 7. C. $37-40$.

8. Хирургическое лечение посттравматической эмпиемы плевры / Ш. Н. Даниелян, М. М. Абакумов, О. В. Воскресенський, Т. В. Черненькая // Хирургия. Журнал имени Н. И. Пирогова. - 2012. - № 3. - С. 4-10.

9. Симонец Е. Н. Профилактика гнойно-воспалительных осложнений грудной стенки у больных с острой эмпиемой плевры [Текст] / Е. Н. Симонец, В. В. Макаров, А. Н. Шкурат // Запорож. мед. журн : науч.-практ. журн. - 2012. - № 6. - С. 38-41.

10. Бойко В. В. Лечебная тактика у больных с многокамерной эмпиемой плевры / В. В. Бойко, В.В.Макаров, В. Г. Грома // Вісн. невідкладної і відновної медицини. $-2012 .-$ T. 13, № 3.- С. 327-330.

11. Surgery and pleuro-pulmonary tuberculosis: a scientific literature review / D. Subotic, P. Yablonskiy, G. Sulis [et al.] // J. Thorac. Dis. - 2016. - No. 8(7). - P. E474-E485.

12. Porcel J. M. Tuberculous pleural effusion / J. M. Porcel // Lung. - 2009. - No. 187. - P. 263-370.

13.Revisiting tuberculous pleurisy: pleural fluid characteristics and diagnostic yield of mycobacterial culture in an endemic area / S. Y. Ruan, Y. C. Chuang, J. Y. Wang [et al.] // Thorax. - 2012. - No. 67. - P. 822-827.

14. Subotic D. Minimally invasive thoracic surgery for empyema / D. Subotic, D. Lardines, A. Hojski // Breathe December. - 2018. - Vol. 14, No. 4. - P. 30-319.

15. Pleural tuberculosis in the United States: incidence and drug resistance / M. H. Baumann, R. Nolan, M. Petrini [et al.] // Chest. - 2007. - No. 131. - P. 1125-1132. 
Огляди літератури, оригінальні дослідження, погляд на проблему, випадок з практики, короткі повідомлення REFERENCES

1. Ceimach, E.A. (2010). Empiema pleury. Operativni metody lecheniya. Chast III [Empyema of pleura. Surgical methods of treatment. Part III]. Tuberkuloz i bolezni legkikhTuberculosis and Pulmonary Diseases, 2, 5-12 [in Russian].

2. Shipulin, P.P. (2010). Primenenaniya raniy dekortikatsii legkogo v lechenii ostroy empiema pleury i nagnoivshegosya svernutogo gemotoraksa [The use of early videothoracoscopic lung decortication in the treatment of acute pleural empyema and suppurating clotted hemothorax]. Klinichna khirurhiia - Clinical Surgery, 10, 29-31 [in Russian].

3. Percev, W.I., Teluzhko, J.W., \& Savchenko, S.I. (2018). Mozhlyvosti ultrasvukovoho doslidzhennia plevralnykh porozhnyn v diahnostitsi stadiia empiemy plevry [Capabilities of ultrasonic pleural emptyness in the diagnosis of stage of pleural empiricism]. Zaporozhkiy Med. Jornal - Zaporozhian Medical Jornal, 20 (4), 487-490 [in Ukrainian].

4. Opanasenko, M.S., Shalahay, S.M., \& Klimets, E.V. (2017). Endoskopichni metody likuvannia pidhostryhh i khronichnykh zapalnykh zakhvoruvan pleury [Endoscopic method of fever and chronic ignition of the pleura]. Klinichna khirurhiia - Clinical Surgery, 1, 39-42 [in Ukrainian].

5. Duzhii, I.D., Hresko, I.Ya., \& Mishenko, Yu.O. (2016). Pytannia epidemiolohii empiemy pleury [Nutrition epidemiological empiric pleuris]. Ukrainskyi pulmonolohichnyi zhurnal - Ukrainian Pulmonogy Journal, 3, 60-63 [in Ukrainian].

6. Balandina, I.A., \& Amarantov, D.G. (2011). Drenirovaniya plevralnoy polosti pri ostroy empieme [Drainage of the pleural cavity in acute empyema]. Khirurgiya imeni N.I. Grekova - Surgery named after N.I. Grekov, 2, 3336 [in Russian].

7. Opanasenko, M.S., Shalagay, S.M., \& Klimets, E.V. (2017). Obhruntuvannia efektyvnosti vykorystannia videoasystovanoho dostupu $v$ khirurhii zapalnykh protsesiv pleury [Substantiation of the effectiveness of video-as-

sisted access in the surgery of inflammatory processes of the pleura]. Klinichna khirurhiia - Clinical Surgery, 7, 37-40 [in Ukrainian].

8. Danilyan, Zh.N. (2012). Khirurgicheskoe lechenie posttravmaticheskoy empiemy pleury [Surgical treatment of post-traumatic pleural empyema]. Khirurhiia. Zhurnal imeni N.I. Pirogova - Surgery. Journal named after N.I. Pirogov, 3, 4-10 [in Russian].

9. Simonets, E.N., Makarov, V.V., \& Zhkurat, A.N. (2012). Profilaktika gnoyno-vospalitelnykh oslozhneniy grudnoy stinky u bolnykh s ostroy empiemoy pleury [Prevention of purulent-inflammatory complications of the chest wall in patients with acute pleural empyema]. Zaporozhkiy Med. Jornal - Zaporozhian Medical Jornal, 6, 38-41 [in Russian].

10. Boyko, V.V., Makarov, V.V., \& Groma, V.G. (2012). Lechebnaya taktika u bolnykh s mnogokamernoy empiemoy pleury [Therapeutic tactics in patients with multichamber pleural empyema]. Visnik nevidkladnoi i vidnovnoi medytsyny - Bulletin of Emergency and Recovery Medicine, 13 (3), 327-330 [in Russian].

11. Subotic, D., Yablonskiy, P., \& Sulis, G. (2016). Surgery and pleuro-pulmonary tuberculosis: a scientific literature review. J. Thorac. Dis., 8 (7), E474-E485.

12. Porcel, J.M. (2009). Tuberculous pleural effusion. Lung, 187, 263-370.

13. Ruan, S.Y., Chuang, Y.C., \& Wang, J.Y. (2012). Revisiting tuberculous pleurisy: pleural fluid characteristics and diagnostic yield of mycobacterial culture in an endemic area. Thorax, 67, 822-827.

14. Subotic, D., Lardines, D., \& Hojski, A. (2018). Minimally invasive thoracic surgery for empyema. Breathe December, 14 (4). 302-319.

15. Baumann, M.H., Nolan, R., \& Petrini, M. (2007). Pleural tuberculosis in the United States: incidence and drug resistance. Chest, 131, 1125-1132.

\title{
ЭФФЕКТИВНОСТЬ УЛЬТРАЗВУКОВОЙ ДИАГНОСТИКИ ТУБЕРКУЛЕЗНОЙ ЭМПИЕМЫ ПЛЕВРЫ
}

๑Ю. Ф. Кошак

\author{
Тернопольский национальный медицинский университет имени И. Я. Горбачевского МОЗ Украинь
}

РЕЗЮМЕ. Представлен первый эффективный анализ ранней диагностики больных туберкулезной эмпиемой плевры с помощью ультразвукового исследования органов грудной клетки. Проанализированы ультразвуковые особенности стадийности, локализации в диагностике туберкулезной эмпиемы плевры в зависимости от пола, возраста, начала, течения и распространенности нагноения.

Цель - улучшить результаты ультразвуковой диагностики больных с туберкулезной эмпиемой плевры путем проведения анализа ценности стандартных методов диагностики.

Материал и методы. Проведен ретроспективный анализ 685 случаев туберкулезной эмпиемы плевры у пациентов, которые за последние 10 лет получили стационарное лечение во фтизиохирургическом отделении «ТОПД". Всем больным были проведены необходимые клинические, лабораторные и инструментальные, включая ультразвуковые, рентгенологические и иммунологические методы обследования.

Результаты. Установлено, что ультразвуковое исследование имеет целый ряд преимуществ и является высокоинформативным методом диагностики плеврального нагноения. По данным эхосканирующего исследования можно спрогнозировать характер плеврального выпота.

Выводы. Только у 51,2 \% больных туберкулезной эмпиемой плевры заболевание было диагностировано своевременно, то есть на стадии возможного малоинвазивного хирургического лечения. Наибольшие диагностические трудности случаются у пациентов с локализацией эмпиемы плевры в зоне активных туберкулезных или 
Огляди літератури, оригінальні дослідження, погляд на проблему, випадок з практики, короткі повідомлення метатуберкулезных изменений. У 48,7 \% больных туберкулезная эмпиема была диагностирована на поздней стадии гнойного процесса, что подтверждает необходимость широкого применения в диагностике ультразвукового исследования.

КЛЮЧЕВЫЕ слОВА: туберкулез; ультразвуковое исследование; туберкулезная эмпиема плевры; видеоторакоскопия; видеоассистованная хирургическая резекция; открытая плеврэктомия с декортикацией легкого.

\section{EFFICACY OF ULTRASONIC DIAGNOSTICS OF PLEURAL TB EMPYEMA}

OYu. F. Koshak

\section{Horbachevsky Ternopil National Medical University}

SUMMARY. The first effective analysis of early diagnosis of patients with tuberculous pleural empyema with the help of ultrasound examination of the chest is presented. Ultrasound features of staging, localization in the diagnosis of tuberculous pleural empyema depending on sex, age, onset, course and prevalence of suppuration are analyzed.

The aim - to improve the results of ultrasound diagnosis of patients with tuberculous pleural empyema by analyzing the value of standard diagnostic methods.

Material and Methods. A retrospective analysis of 685 cases of tuberculous pleural empyema in patients who received inpatient treatment in the Phthisiosurgical Department Ternopil Regional TB Dispensary for the last 10 years. All patients underwent the necessary clinical, laboratory and instrumental, including ultrasound, X-ray and immunological methods of examination.

Results. It is established that ultrasound examination has a number of advantages and is a highly informative method of diagnosing pleural suppuration. According to the echoscanning study, the nature of pleural effusion can be predicted.

Conclusions. Only $51.2 \%$ of patients with tuberculous pleural empyema were diagnosed in time, ie at the stage of possible minimally invasive surgical treatment. The greatest diagnostic difficulties occur in patients with localization of pleural empyema in the area of active tuberculous or metatuberculous changes. In $48.7 \%$ of patients, tuberculous empyema was diagnosed at a late stage of the purulent process, which confirms the need for widespread use in the diagnosis of ultrasound.

KEY WORDS: tuberculosis; ultrasound; tuberculous empyema of the pleura; videothoracoscopy; video-assisted surgical resection; open pleurectomy with lung decortication. 